\title{
PLAGIOSTACHYS NICOBARICA (ZINGIBERACEAE), NEW GENERIC RECORD AND A NEW SPECIES FROM THE NICOBAR ISLANDS, INDIA
}

\author{
M. SABU, E. SANOJ \& M.G. PRASANTH KUMAR \\ Department of Botany, University of Calicut, \\ P.O. Calicut University, 673635 Kerala, India
}

\begin{abstract}
SUMMARY
Plagiostachys nicobarica, a new generic record and a new species from the Nicobar Islands, India, is described and illustrated. The genus, so far known from China, Indonesia, Malaysia, the Philippines and Thailand, is now reported from India.
\end{abstract}

Key words: Zingiberaceae, Plagiostachys nicobarica, India, new generic record, new species.

\section{INTRODUCTION}

The family Zingiberaceae, one of the largest monocotyledonous families of the Indian subcontinent, is represented by 22 genera and about 180 species (Jain \& Prakash 1995). Even though several notable studies on this family have been carried out during the past several years in India, survey of remote areas has been regularly bringing out new discoveries (Sabu \& Mangaly 1991, Jain \& Prakash 1995, Srivastava 1998, Skornickova \& Sabu 2005a, b, Sabu 2006). Srivastava (1998) carried out remarkable work on the Zingiberaceae of Andaman \& Nicobar Islands and enumerated 23 species in 10 genera, both wild and naturalized. Recent work by Larsen (1997), William et al. (2004) and Skornickova \& Sabu (2005a, b) have reduced the total number of genera to 19 from 22 by the transferring of Curcumorpha to Boesenbergia, Mantisia to Globba and Paracautleya to Curcuma.

As part of a Department of Science and Technology (DST) project, the authors visited the Andaman Islands in April 2002 for the study of Gingers in that region. While studying the herbarium specimens at the Andaman \& Nicobar Circle of the Botanical Survey of India at Port Blair (PBL) four collections $(2977,3832,3933,7162)$ drew the attention. Two of them $(3832,3933)$ have been misidentified at family level and placed under Marantaceae. The other two $(2977,7162)$ were determined as Cautleya Hook.f. But the position of the inflorescence and scanty notes on the labels clearly indicated that they belong to the genus Plagiostachys Ridl. However, the notes on the labels are insufficient for species delimitation.

Our team again visited the Nicobar Islands in 2003 and 2007 to collect Plagiostachys specimens. They could collect specimens in fruiting and flowering stage. The rhizomes were planted in the Calicut University Botanical Garden (CUBG) and flowered in November 2003. A critical study of specimens in comparison with other species has 

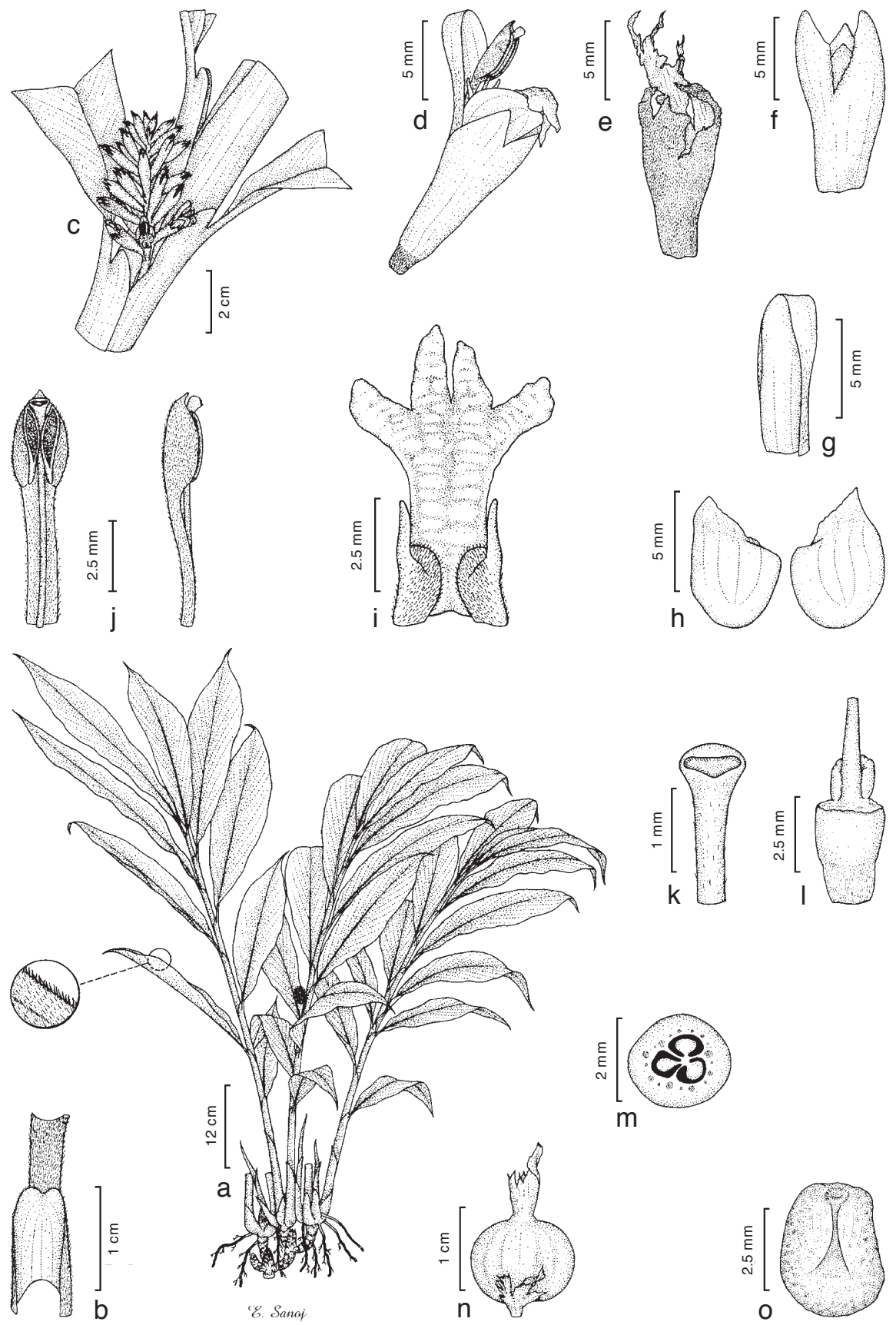

Fig. 1. Plagiostachys nicobarica M.Sabu, E.Sanoj \& M.G.Prasanth. a. Habit; b. ligule; c. inflorescence; d. single flower; e. bracteole; f. calyx; g. dorsal corolla lobe; h. lateral corolla lobes; i. labellum; j. anther (front and lateral views); k. stigma; 1. ovary with epigynous glands; m. cross section of ovary; n. fruit; o. seed (all: Thomas \& Shameer 113609). 
proved that this plant is distinct from described species. Specimens and photographs were sent to Prof. Kai Larsen, Aarhus University for confirmation.

The genus Plagiostachys was established by Ridley (1899). Earlier he treated it as a species of Amomum, A. laterale Ridl. He suggested that this genus is closer to Alpinia than to Amomum. Holttum (1950), however, was of the opinion that Plagiostachys is more allied to Amomum. Smith (1985) supported Ridley's view and stated that affinity may equally lie with Alpinia and in particular with A. hansenii R.M.Sm. and A. havilandii K.Schum., those with laterally produced inflorescences. Kress et al. (2002) showed the paraphyletic nature of the genus Plagiostachys. As this work is incomplete we are describing this species in a paraphyletic genus. Presently, the genus includes 19 species (Newman et al. 2004), mainly distributed in China and South-east Asia (Wu \& Larsen 2000, Maknoi \& Sirirugsa 2002, Newman et al. 2004). Present literature shows that the flora of the Nicobar Islands is more close to that of Malaysia than to that of Myanmar, Thailand or India (Turner et al. 2001).

Plagiostachys nicobarica M.Sabu, E.Sanoj \& M.G.Prasanth, spec. nov. - Fig. 1; Plate 1

Plagiostachydi sumatrensi Ridl. similissimo, foliis brevioribus, laminis utrinque pubescentibus, inflorescentia simplici, floribus albis, calyce corolla capsulo majore differt. - Typus: Thomas \& Shameer 113609 (holo CALI; iso MH, K), India, Nicobar Islands, Great Nicobar, 12.7 km on East West Road, 27.09.2007.

Perennial rhizomatous herbs. Rhizome 6-8 mm wide, branched, spreading laterally, subterranean, creamy white within, slightly aromatic, internodes compressed, covered by brown and decayed sheaths, young shoots and roots arise mostly from the base of older shoots. Leafy shoots $55-75 \mathrm{~cm}$ long, form a dense clump, slightly bend, basal 2 or 3 sheaths leafless, 9-12-leaved. Ligule 3.4-4 mm long, light green, coriaceous, tip notched, densely pubescent along the margin and externally. Petiole $1-1.5 \mathrm{~cm}$ long, green, pubescent. Lamina elliptic, $33-37$ by $8.4-9.2 \mathrm{~cm}$, base slightly oblique, attenuate, margin slightly undulate, ciliate, apex acuminate, slightly twisted to one side, bend down; upper surface bright green, lower surface light green, pubescent on both surfaces, more dense beneath; midrib yellowish green. Inflorescence $4-12.5$ by $0.3-3.5 \mathrm{~cm}$, terminal raceme, slightly mucilaginous, produced through lateral slits of sheaths of aerial shoot about $28-35.5 \mathrm{~cm}$ from the base; peduncle pale green, pubescent. Sterile bracts 3 or 4, mostly included within the sheaths; outermost elliptic-linear, 3.7-5.8 by $0.5-0.8$ $\mathrm{cm}$, tubular about $2-3 \mathrm{~mm}$ at base, innermost ovate elliptic, $1.5-1.8$ by $0.5-0.6 \mathrm{~cm}$, pubescent externally. Bracteoles tubular, 14-17 by 4-4.5 mm, white, leathery, densely pubescent externally, single flowered, completely covering the young buds, on aging upper half irregularly broken, early dried off, persistent. Flower 1.7-1.8 cm long, 1-3 open at the same time. Pedicel $0.5-1.5 \mathrm{~mm}$ long, pubescent. Calyx tubular, 10-11 by 4-5 mm, white, fleshy, glabrous, glossy, upper part rarely decaying, 3-toothed; teeth 5-6 mm long, hooded; mouth margin early dried off, slightly ciliate. Corolla tube 4-5 mm long, 3-3.5 mm wide at mouth, white, glabrous, internally hairy at the mouth, hairs downwardly directed. Corolla lobes pale greenish white, pellucid; dorsal lobe oblong, boat-shaped, $8-8.5$ by $5-5.5 \mathrm{~mm}$, pubescent externally at base, glabrous towards tip, 5-veined, hooded at tip; lateral lobes broadly ovate, $6-7$ by $4.5-5 \mathrm{~mm}$, glabrous, 

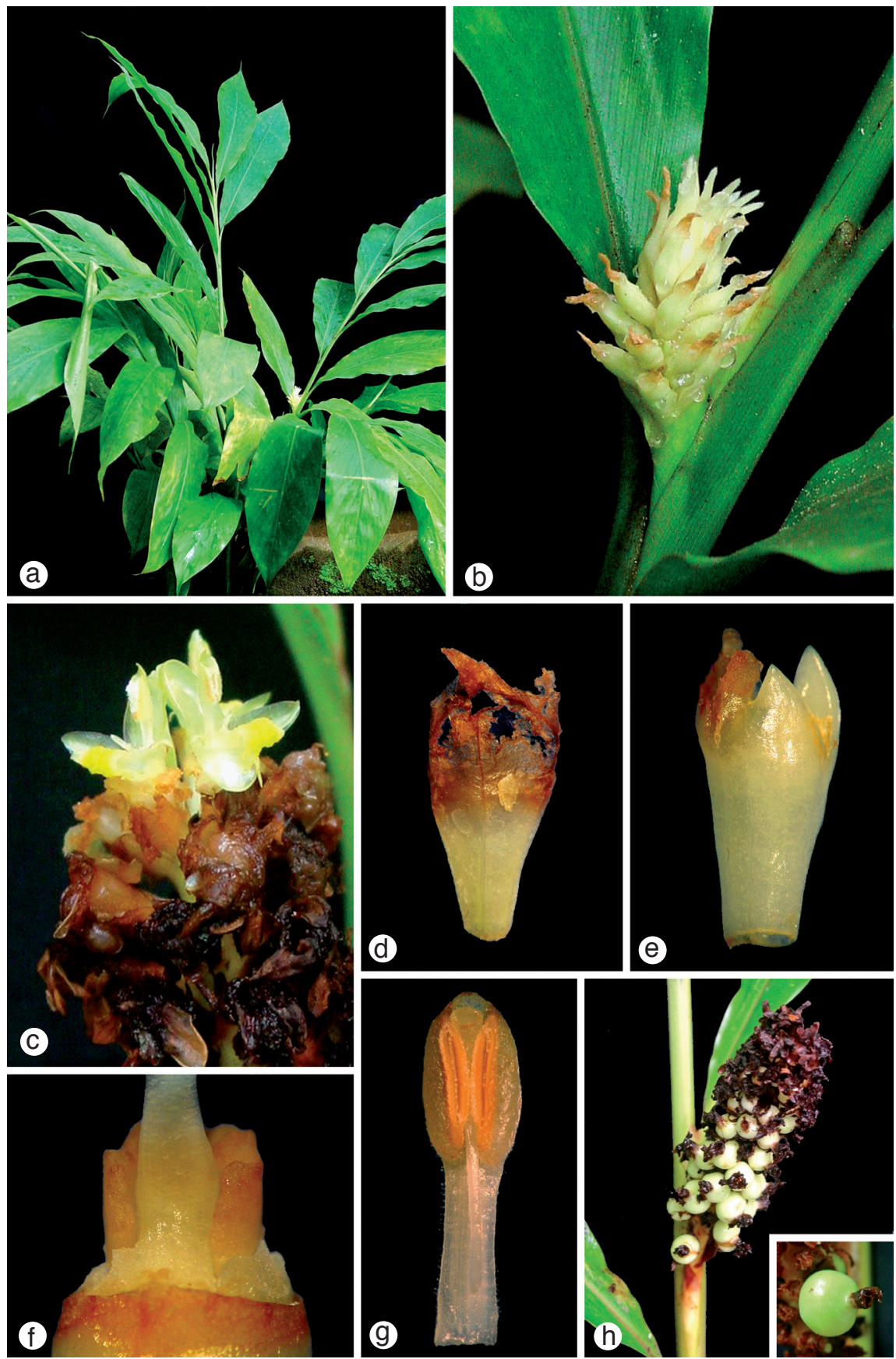

Plate 1. Plagiostachys nicobarica M.Sabu, E.Sanoj \& M.G.Prasanth. a. Habit; b. inflorescence coming out through lateral slits of the pseudostem; c. close-up of inflorescence; d. bracteole with decaying tips; e. calyx; f. epigynous glands and style base; g. stamen; h. infructescence. - Photos by Sabu and Sanoj. 
3-veined, tip rounded, recurved. Labellum spathulate, $7.5-8$ by $4.5-5 \mathrm{~mm}$, yellow, creamy white towards margin, transversely ribbed, distinctly 3-lobed, lobes unequal, middle lobe 2-2.5 mm long, deeply emarginated, margins crumpled; tip recurved. Lateral staminodes thumb-shaped, $2-2.5$ by $0.5 \mathrm{~mm}$, yellow, base swollen, covered with gland-tipped hairs, upper part subulate. Stamen 8-8.5 mm long; filament 5-5.5 by $1 \mathrm{~mm}$, flat, white, glandular hairy; anther ovate, $3-3.5$ by $2 \mathrm{~mm}$, creamy white, densely glandular hairy; thecae parallel, slits longitudinal, opening only up to upper $3 / 4$ of its length, margins hairy; crest c. $0.5 \mathrm{~mm}$ long, beak-like, creamy white, glabrous. Ovary barrel-shaped, $1.75-2$ by $2-2.25 \mathrm{~mm}$, white, glabrous, glossy, 3-locular, each locule with 2 ovules, on axile placenta. Style white, filiform, base swollen, sparsely hairy on upper half, free from corolla tube; stigma cup-shaped, creamy white, coming out through anther thecae; mouth lateral, margin ciliate. Epigynous glands single, girdle-shaped, c. 1.5 by $1.5 \mathrm{~mm}$, pale brown, glabrous, encircling $3 / 4$ of style base. Capsule globose, $0.8-0.9$ by $1-1.1 \mathrm{~cm}$, pale white, glabrous, longitudinally ribbed, 3-locular, with persistent bracts and calyx. Seeds $4-6,3.5-4$ by $3-3.5 \mathrm{~mm}$, surface slightly warted with an abaxial central groove. Aril white, fleshy, completely encircles the seed.

Distribution - Endemic to the Nicobar Islands, near Indira point in the Great Nicobar Islands.

Habitat - Wet evergreen forests rich in humus at sea level. Flowering and fruiting: July to January.

Etymology - The specific epithet 'nicobarica' indicates the place of collection, the Nicobar Islands.

Notes - Plagiostachys nicobarica is allied to P. sumatrensis but differs in leaf size, branching of inflorescences, flower colour and sizes of flower parts and fruits (Table 1).

The species is only known from the type locality and surroundings. These areas are at present under water from the Tsunami flood. Approximately $60 \%$ of the specimens are lost and remaining specimens are in danger of being wiped out at any time.

Other specimens examined:

INDIA: Balakrishnan 2977 (PBL), South Nicobars, Great Nicobar Island; 8 km on East West road, 19.8.1975; Prasanth 92614 (CALI), 12 km on East West road, 13.08.2003; Balakrishnan 3933 (PBL), 34 km on East West road, 22.7.1976; N.G. Nair 7162 (PBL), towards Pygmalion point, 2.12.1978; Balakrishnan 3832 (PBL), $20 \mathrm{~km}$ on road to Pygmalion point, 17.7.1976.

Table 1. Comparison of major characters of P. nicobarica and P. sumatrensis.

\begin{tabular}{|c|c|c|}
\hline Characters & P. nicobarica & P. sumatrensis \\
\hline Leaves & $\begin{array}{l}34-38.5 \text { by } 8.4-9.2 \mathrm{~cm} \text {, elliptic, } \\
\text { pubescent on both surfaces }\end{array}$ & $\begin{array}{l}52 \text { by } 8 \mathrm{~cm} \text {, linear-oblong, upper } \\
\text { glabrous, lower velutinous, cuspidate }\end{array}$ \\
\hline Inflorescence & unbranched & branched \\
\hline Flower & white & yellow \\
\hline Calyx & $1-1.1 \mathrm{~cm}$ long & $2 \mathrm{~mm}$ long \\
\hline Corolla tube & $4-5 \mathrm{~mm}$ long & $2 \mathrm{~mm}$ long \\
\hline Corolla lobes & $6-8.5 \mathrm{~mm}$ long & $4 \mathrm{~mm}$ long \\
\hline Capsule & $1-1.1 \mathrm{~cm}$ diameter & $4 \mathrm{~mm}$ diameter \\
\hline
\end{tabular}




\section{ACKNOWLEDGEMENTS}

The research grant provided by the Department of Science and Technology, Government of India for the revision of Indian Zingiberaceae (Order No.SP/SO/PS-52/2005) is gratefully acknowledged. We are also grateful to Prof. Kai Larsen, Aarhus University, Denmark for his valuable opinion on the species and Dr. J.F. Veldkamp, Leiden, The Netherlands for the Latin diagnosis. Thanks are also due to Mrs. Jana Skornickova, Singapore Botanic Garden for identifying the herbarium specimen at PBL and various suggestions provided throughout the work. We are thankful to the officers of the Forest Department, Andaman \& Nicobar Islands for permission and timely help in the field. We are also thankful to the Deputy Director, Botanical Survey of India, Port Blair and other staff of the circle for their assistance during our visit. Various help rendered by Dr. A.K. Pradeep, Curator, Calicut University Herbarium (CALI) during the exploration is also gratefully acknowledged.

\section{REFERENCES}

Holttum, R.E. 1950. Zingiberaceae of the Malay Peninsula. Gard. Bull. Singapore 13: 1-249.

Jain, S.K. \& V. Prakash. 1995. Zingiberaceae in India: Phytogeography and endemism. Rheedea 5: $154-169$.

Kress, W.J., L.M. Prince \& K. J. Williams. 2002. The phylogeny and new classification of the gingers (Zingiberaceae): Evidence from molecular data. Amer. J. Bot. 89: 1682-1696.

Larsen, K. 1997. Further studies in the genus Boesenbergia (Zingiberaceae). Nordic J. Bot. 17: 361-366.

Maknoi, C \& P. Sirirugsa. 2002. New records of Zingiberaceae from Southern Thailand. Nat. Hist. Bull. Siam Soc. 50: 225-237.

Newman, M., A. Lhuilliet \& A.D. Poulsen. 2004. Checklist of the Zingiberaceae of Malesia. Blumea, Suppl. 16.

Ridley, H.N. 1899. The Scitaminae of Malay Peninsula. J. Straits Branch Roy. Asiat. Soc.: 85-184.

Sabu, M. 2006. Zingiberaceae and Costaceae of South India. Indian Association for Angiosperm Taxonomy, Kerala.

Sabu, M. \& J.K. Mangaly. 1991. Alpinia smithiae (Zingiberaceae), a new species from South India. Edinburgh J. Bot. 48: 69-71.

Skornickova, J. \& M. Sabu. 2005a. The recircumscription of Curcuma L. to include the genus Paracautleya R.M.Sm. Gard. Bull. Singapore 57: 37-46.

Skornickova, J \& M. Sabu. 2005b. Curcuma roscoeana Wall. (Zingiberaceae) in India. Gard. Bull. Singapore 57: 199-210.

Smith, R.M. 1985. Review of Bornean Zingiberaceae: 1 (Alpiniae p.p.). Notes Roy. Bot. Gard. Edinburgh 42: 261-314.

Srivastava, S.K. 1998. Zingiberaceae in Andaman and Nicobar Islands, India. Higher Pl. Indian Subcontinent. Indian J. Forest., Add. Ser. 8: 1-33.

Turner, H., P. Hovenkamp \& P.C. van Welzen. 2001. Biogeography of Southeast Asia and the West Pacific. J. Biogeogr. 28: 217-230.

William, K.J., W.J. Kress \& P.S. Manos. 2004. The phylogeny, evolution and classification of the genus Globba and tribe Globbeae (Zingiberaceae). Appendages do matter. Amer. J. Bot. 91: 100-114.

Wu, T.L \& K. Larsen. 2000. Zingiberaceae. In: C.Y. Wu \& H.R. Peter (eds), Flora of China. Vol. 24. Science Press, Beijing. 